\title{
LA INFLUENCIA DEL DERECHO FORAL EN LA RECONQUISTA DE ESPAÑA
}

\begin{abstract}
Sumario: I. Introducción. II. La antigua Hispania. III. La sociedad medieval española. IV. La Reconquista y la repoblación. V. Naturaleza del derecho medieval. VI. El derecho foral en la España medieval. VII. El derecho foral contemporáneo. VIII. Conclusiones. IX. Bibliografia y hemerografía.
\end{abstract}

Carlos Hernández Toledo*

\section{INTRODUCCIÓN}

Uno de los momentos más importantes para la comprensión de la historia del derecho preconstitucional continental es, sin duda alguna, el relativo al medievo español. Un estado marcado por la conquista árabe que dejó su impronta en varios aspectos de la sociedad española medieval que perviven hasta nuestros días, ${ }^{1}$ entre ellos, por ejemplo, la ampliación del léxico utilizado hasta esa época, a través de la introducción a lo largo de más de ocho siglos de presencia islámica, de un sinnúmero de vocablos conocidos como arabismos. $^{2}$

\footnotetext{
* Secretario de Estudio y Cuenta del Tribunal Electoral del Poder Judicial de la Federación.

1 Incluso el historiador Joseph Pérez señala que con la llegada de los musulmanes "España desde el punto de vista religioso se islamizó y desde el punto de vista lingüístico y cultural, se arabizó". Pérez, Joseph, La historia de España, trad. de Juan Vivanco, Magda Mirabet y M. Carmen Doñate, Barcelona, Crítica, 2006, p. 5.

2 Según el Diccionario de la lengua española, un arabismo es un vocablo o giro de la lengua árabe empleado en otra.
} 
Resulta relevante que en ese ambiente oscurantista, el derecho, como un conjunto de normas consuetudinarias carentes de una fuente legislativa propiamente dicha - e incluso de la idea de un Estado como tal-, tuviera un rol social determinante en el surgimiento, estructura y organización de asentamientos humanos que a la postre representarían la unificación y Reconquista de España.

Así, los fueros entendidos como compilación de leyes de un territorio determinado ${ }^{3}$ se convirtieron en el marco normativo de comunidades y asentamientos en las diversas regiones de la península española que, en tal virtud, gozaron de la vigencia de un derecho de clara raigambre consuetudinaria. En esa dinámica evolucionista, los fueros se fueron convirtiendo en grandes esfuerzos compilatorios y de sistematización de las normas vigentes en ese periodo.

Es bajo esta perspectiva que se analizará el rol determinante de los citados fueros y las llamadas cartas pueblas - concebidas básicamente como documentos fundacionales, otorgadas a los pobladores de nuevos territorios - $;{ }^{4}$ la importancia que tuvieron en el largo proceso de Reconquista de España, sin dejar de lado las vicisitudes que dicho proceso presentó; el papel relevante de la mujer en su consolidación, y la influencia que los mismos tienen hoy en el derecho contemporáneo español. ${ }^{5}$

De esa forma, se observará el papel que el derecho, aun en su forma menos sofisticada, puede tener como instrumento de desarrollo social, así como en el nacimiento, evolución y consolidación de instituciones y formas de gobierno, a través de lo que ya Maine identificaba como sus tres principales recursos que se suceden en el tiempo: "las ficciones legales, la equidad y la legislación". ${ }^{6}$

En esa tesitura, este trabajo no es una recopilación de fechas y acontecimientos históricos pormenorizados de la conquista y Reconquista de España, sino más bien, un esfuerzo por destacar los aportes y repercusiones que el derecho foral medieval pudo tener en la fundación y composición del actual territorio español y cuyos ecos parecen tener presencia en la actualidad.

3 Diccionario jurídico mexicano, 14a. ed., México, UNAM, Instituto de Investigaciones Jurídicas, 2000, t. II, p. 1489.

4 Ibidem, p. 1490.

5 Lo que explica una de las obras más célebres de los últimos años en el ámbito académico español: Castán Tobeñas, José, Derecho civil español, común y foral, Madrid, Reus, 1975; objeto de varias reimpresiones y actualizaciones.

6 Maine, Henry, El derecho antiguo, trad. de Ramón Cotarelo, Valencia, Tirant lo Blanch, 2014, p. 23. 


\section{LA ANTIGUA HisPaniA}

Hispania fue el nombre con el que se conoció a la entonces península ibérica durante el imperio romano. En la etapa previa a la llegada de los musulmanes, precedida por una precaria condición económica y social en la península, "fueron varias las influencias prerromanas [que] habían coexistido en la península española: celtas, invasores desde el norte; los iberos, los fenicios y los griegos", quienes convivieron con los nativos que practicaban sus costumbres romanas en regiones remotas y que "en el año 73 o 74 d. C., recibirán un estímulo a la romanización cultural que se extendió al derecho aplicable, cuando Roma concedió la ciudadanía a los españoles libres".?

De manera paralela, la religión católica adquirió condición oficial ${ }^{8}$ con la consecuente serie de acontecimientos que tal hecho, por sí mismo, entraña en cuanto a su influencia en la vida social y cultural de cualquier región. Asimismo, en los siglos posteriores, la península hispánica fue motivo de una invasión visigoda ${ }^{9} \mathrm{y}$ de una conquista por parte del emperador bizantino Justiniano. Ello hizo posible que "desde entonces comenzara a formarse con elementos germánicos y romanizados una nueva nación hispánica, con un idioma propio, un auténtico sentimiento de solidaridad y con una frontera natural como los Pirineos". ${ }^{10}$

Fue en 711 el inicio del periplo árabe que duraría más de setecientos años hasta la caída de Granada, uno de los últimos bastiones musulmanes en 1492. Detrás de su partida, los árabes dejaron una estela de aportaciones que marcarían la vida social y cultural de los nuevos españoles que de manera progresiva fueron repoblando los territorios usurpados, conformando comunidades o poblaciones que se regían por ciertas normas forales y consuetudinarias, organizadas básicamente bajo una estructura feudal, cuya característica particular fue "la existencia de fueros medievales que marcaron al feudalismo español como el Fuero de Tudela de 1112 para Aragón y el Fuero de los Fijosdalgo de 1138 para Castilla". ${ }^{11}$

7 Margadant S., Guillermo F., Introducción a la historia del derecho mexicano, México, Esfinge, 1986, p. 28.

8 Aunque se dice también que, junto a la religión católica, subsistió la musulmana y la judía, lo que Joseph Pérez denomina "la España de las tres religiones", donde el reinado posterior de los reyes católicos marcaría una nueva era de dominación española durante más de dos siglos.

9 No obstante, la presencia de los visigodos fue relativamente menor, "menos de un dos por ciento frente a cuatro o cinco millones de hispanorromanos". Pérez, Joseph, op. cit., p. 17.

10 Margadant S., Guillermo F., Introducción a la ..., cit., p. 28.

11 Margadant S., Guillermo F., Panorama de la historia universal del derecho, México, Miguel Ángel Porrúa, 1998, p. 159. 
No tardaría mucho para que la estratificación feudal comenzará a perder vigencia. Con la "aparición de la moneda y el surgimiento de nuevas ciudades", se aceleró la liberalización de los lazos feudales por parte de las personas pertenecientes a los estratos inferiores, quienes posteriormente adquirían el estatus de ciudadanos de las nuevas ciudades que se iban conformando, ${ }^{12}$ bajo una cada vez mayor "política centralizadora de los reyes que con frecuencia lograban imponerse a los nobles feudales, sustituyéndolos por funcionarios asalariados". ${ }^{13}$

En ese estado de cosas, para el historiador Joseph Pérez:

la clave de la historia de España durante la Edad Media está precisamente [...] en el esfuerzo de los españoles durante siglos para reincorporarse cuanto antes al mundo occidental y evitar a la península el destino del norte de África, es decir, el de unas provincias romanizadas y cristianizadas que acaban formando parte del mundo islámico, ese esfuerzo es el que se conoce con el nombre de Reconquista. ${ }^{14}$

Lo cual, como se verá más adelante, repercutió allende las fronteras hispánicas.

\section{LA SOCIEDAD MEDIEVAL ESPAÑOLA}

Cuando se habla de la Edad Media es común pensar en una etapa anquilosada de la historia de la humanidad. Se suele traer a la mente imágenes de castillos, fortalezas, reyes, reinas y príncipes, de señores feudales y de una casta eclesiástica pletórica de poder y de influencia, así como de vastas tierras dedicadas básicamente a la agricultura, que servían al mismo tiempo como escenario de grandes y sangrientas batallas épicas. ${ }^{15}$

12 Ello, tomando en cuenta que "el rasgo destacable de la civilización hispanomusulmana era la de ser una sociedad esclavista". Pérez, Joseph, op. cit., p. 25.

13 Margadant S., Guillermo F., Panorama de..., cit., p. 161. Para Floris Margadant, "el feudalismo tuvo una influencia decisiva, no sólo para la estratificación de la sociedad, sino también para el surgimiento de los parlamentos modernos; las comisiones de los grandes señores feudales, como las que circundaban a los reyes, con la obligación de aconsejarlos y de asumir, así, cierta corresponsabilidad en los actos de gobierno, son el punto de partida del parlamentarismo moderno".

14 Pérez, Joseph, op. cit., pp. 5 y 6.

15 Es notoria la influencia que el cine y la literatura han tenido en la sedimentación de dichas imágenes. Pero en especial, el séptimo arte. Muestra de ello, son las películas: En el nombre de la rosa de Jean-Jacques Annau (1986), Excalibur de John Boorman (1981), El 
Incluso para el gran jurista italiano Paolo Grossi, "a lo largo de la Edad Media el sustantivo Europa tuvo un contenido exclusivamente geográfico, [refiere que] es con el Humanismo cuando el término asume el significado de valores espirituales y culturales, dando inicio a una veta de reflexiones que más tarde alcanzará su plenitud", ${ }^{16}$ y que se enmarcará con una evolución de las ideas políticas que muy pronto irrumpirán en el mundo renacentista, ávido de encontrar nuevas formas y normas de entendimiento social y de legitimación del Estado. Ese desarrollo llevará al propio Grossi a plantearse, siglos después, el dilema de "si la visión del derecho es la misma en la Edad Media, la Moderna y la posmodernidad", con un solo hilo conductor, "o existieron visiones distintas, o incluso opuestas", y concluye que la presencia que se muestra "ante nuestros ojos con toda evidencia" es la de rostros "distintos y peculiares". ${ }^{17}$

No obstante, más allá de esa primera impresión respecto de la Edad Media y el derecho imperante en la misma, dicha época también representa en el caso particular de España, el inicio de su consolidación como Estado nación multinacional independiente, desligada por completo del otrora imperio romano. Ello, aun cuando dicha afirmación podría resultar un tanto paradójica si se considera que entre los siglos VIII y XV la entonces Hispania estuvo bajo la presencia y dominación de los musulmanes, cuyo expulsión definitiva se produce en 1492, "cuando los moros pierden con Granada su último baluarte en la península, encontrando la energía española y su fervor catequizante inmediatamente una nueva salida en la labor conquistadora y cristianizadora del Nuevo Mundo descubierto en ese mismo año". ${ }^{18}$

$\mathrm{Y}$ es que fue durante el medievo, cuando se consolidaron los grandes reinos españoles (Asturias, Navarra, León, Galicia, Portugal y Castilla), que tiempo después, con base en matrimonios arreglados y pactos coyunturales, conformarían la Corona española, ${ }^{19}$ misma que una vez culminado el largo y tortuoso proceso de Reconquista, llegaría a conformar un gran imperio a

séptimo sello del influyente Ingmar Bergman (1957), Andréi Rubliov del gran director esteticista Andréi Tarkovski (1964) y la más comercial de todas Corazón Valiente de Mel Gibson (1995), así como la exitosa serie Game of Thrones, de ambientación medieval, dirigida por Thomas McCarthy.

16 Grossi, Paolo, Europa y el derecho, trad. de Luigi Giuliani, Barcelona, Crítica, 2008, pp. 13 y 14 .

17 Ibidem, pp. 16 y 17.

18 Margadant S., Guillermo F., Introducción a la ..., cit., p. 30.

19 Cfr. Suárez Bilbao, Fernando, "El modelo de organización política de la monarquía universal: la corona de Aragón y su proyección en las Indias", Revista Mexicana de Historia del Derecho, México, vol. XXX, julio-diciembre de 2014, pp. 3-87. En dicha obra se destaca 
raíz de la ocupación de América. ${ }^{20}$ Es decir, pasaron más de siete siglos desde que "en el año 711 un ejército musulmán invadió la Península Ibérica y la conquistó", hasta 1492, fecha en la que "los Reyes Católicos de Aragón y Castilla tomaron Granada, último estado musulmán independiente de la península". Fue entre esos dos momentos, "que el poder político fue pasando de manos musulmanas a manos cristianas". ${ }^{21}$ Transición en la que el derecho foral desempeñó un papel crucial en la regulación de las relaciones sociales de las nuevas comunidades que se fueron asentando a lo largo y ancho del actual territorio ibérico.

Se tiene incluso que fue durante la baja Edad Media cuando se dio "el surgimiento de las ciudades, lo cual cambió el panorama político de España". ${ }^{22}$ Floris Margadant destaca la penetración que los burgueses tuvieron en la cortes españolas, "balanceando el poder de los señores feudales, arrancando, por un hábil juego diplomático, a la Corona varios privilegios", ${ }^{23}$ entre ellos, el reconocimiento o imposición de sus propios privilegios o sistemas normativos.

\section{LA RECONQUISTA Y LA REPOBLACIÓN}

Durante la llamada Reconquista, tuvieron lugar "los procedimientos administrativos, estructurales sociales, tipos humanos y mentalidades que conquistarían y colonizarían los imperios ultramarinos después de 1492", cuyo influjo, a decir del hispanista inglés Derek Lomax, tuvo "un efecto decisivo sobre el carácter nacional de España". ${ }^{24}$ Para dicho autor, la Reconquista "es un marco conceptual útil a los historiadores, pero no artificial como la Edad

\footnotetext{
"el pactismo" que aconteció entre los diversos reinos de esa época con miras a mantener un "equilibrio entre el ámbito de facultades del monarca y las leyes del reino", p. 4.

20 Ese hecho histórico resulta determinante para la "invención de Europa", pues "aceleró la ruptura con la Edad Media, un nuevo grupo humano, una nueva fuerza cultural y una nueva geografía produjeron un importante impacto en el espacio europeo, en un momento en el que las artes y la ciencia ya habían comenzado a experimentar profundas transformaciones a partir del siglo $\mathrm{XV}$, la fuerza del contraste y la conciencia de haber encontrado un mundo nuevo también ayudaron a poner fin a la fragmentación medieval". Véase Valadés, Diego, "Estudio introductorio", en Häberle, Peter, El Estado constitucional, trad. de Héctor FixFierro, Buenos Aires, Astrea, 2007, pp. 27-29.

21 Lomax, Derek W., La Reconquista, trad. de Antonio Prometeo Moya, Barcelona, Crítica, 1984, p. 9.

22 Margadant S., Guillermo F., Introducción a la ..., cit., p. 31.

23 Ibidem, p. 32.

24 Lomax, Derek W., op. cit., p. 9.
} 
Media"; desde su óptica, dicho proceso fue "un ideal alumbrado por cristianos hispánicos poco después de 711", señala que en ocasiones "se ha insinuado que durante siete siglos todas las empresas de los cristianos españoles fueron motivadas exclusivamente por el anhelo de Reconquista", en el que los cristianos que la protagonizaron creían que "estaban rescatando a España para el dominio político cristiano". ${ }^{25}$

Así, bajo la visión de Lomax, la Reconquista fue una tarea excepcional por su duración y por el simple hecho de que ese objetivo político sobrevivió durante más de setecientos años, convirtiéndose en un propósito continuado por múltiples generaciones de adeptos, ${ }^{26}$ hipótesis que no es compartida por diversos investigadores.

Por otro lado, de manera paralela a dicho fenómeno, Oscar Cruz Barney destaca como eje adicional de la historia moderna española "la repoblación de los territorios ocupados, a partir de la formación de los primeros reinos cristianos". ${ }^{27}$ Precisa que la Reconquista partió de distintos núcleos políticos independientes como lo fueron los reinos de Cataluña, Navarra, Aragón, Asturias, Castilla, Valencia y Mallorca. Además, plantea que esa fragmentación del poder político aunado al aumento de las facultades de los señores feudales, quienes gozaban de cierta capacidad generadora de derecho mediante el otorgamiento de fueros y privilegios, propició "un fenómeno de dispersión jurídica", ${ }^{28}$ que se alimentaba del hecho de que dentro de un mismo reino los hombres gozarán de diversa condición jurídica, por tanto "dentro de una misma ciudad las personas se distinguían jurídicamente a partir de su religión, su nación y su estrato social", ${ }^{29}$ lo que explica la existencia entonces de distintos fueros o sistemas normativos o de un derecho eminentemente de carácter local.

25 Ibidem, p. 10. Llama la atención que es el mismo Lomax quién señala a ciertos profesores británicos (Watts, Lane-Poole y Trend) como los autores de una tesis contraria a la mencionada, pues para ellos los españoles cristianos muchas veces "carecían de interés en la Reconquista, [ya que] tenían relaciones amistosas con los musulmanes y se comportaban de manera hostil y traidora con sus correligionarios". En el mismo sentido, Oscar Cruz Barney refiere que la Reconquista fue "elevada a una categoría mítica", como si la recuperación de las tierras ocupadas hubiera sido un programa de "acción constante y colectivo", lo cual dice, no es del todo acertado. Cruz Barney, Oscar, Historia del derecho en México, México, Oxford University Press, 2004, p. 63.

26 Lomax, Derek W., op. cit., p. 63.

27 Cruz Barney, Oscar, op. cit., p. 61.

28 Ibidem, p. 62.

29 Ibidem, p. 63. 
Asimismo, abunda en la descripción de los diferentes procesos de repoblación, ${ }^{30}$ a los cuales etiqueta como uno de los principales motores del dinamismo en la sociedad de los siglos IX a XIII, por tanto indica que la aplicación del derecho en una población determinada dependía en gran medida, "de cuándo, con qué régimen jurídico y con quiénes se repobló una comarca, una ciudad o un reino". ${ }^{31}$ Para tal efecto, distingue entre la repoblación de zonas despobladas y de ciudades, entre la organizada por los reyes y una espontánea, ya fuera a partir de la actividad del clero o ya fuera por iniciativa de los propios habitantes, repoblación esta última a la que atribuye un carácter inorgánico, destacando diversas fases y zonas, como la de Cataluña, la del Valle del Duero, la del reino de Toledo, la del Valle del Ebro, la de Andalucía, la de Mallorca, la de Valencia y la de Murcia.

Al tener claro este devenir histórico del pueblo español medieval y esta misión reconquistadora y repoblacional, parece ser que la posterior conquista de América fue una tarea natural, inevitable y consecuente de ese espíritu fundacional forjado por más de siete siglos de ocupación árabe que le proporcionó el know how adecuado y suficiente para una tarea de dicha envergadura y que encontró en las tierras americanas el espacio propicio para su reafirmación. En ese mismo sentido, concluye Lomax que "sólo España era capaz de conquistar, administrar, cristianizar y europeizar las populosas zonas del Nuevo Mundo precisamente porque en el curso de los siete siglos anteriores había organizado su propia sociedad con la finalidad de conquistar, administrar, cristianizar y europeizar a los habitantes de Al-Andaluz". ${ }^{32}$

30 Es interesante para el éxito de dicho proceso que los nuevos pobladores tuvieran cierta seguridad jurídica sobre los predios que iban reconquistando. Como parte de ese régimen de propiedad territorial se tuvo la figura de la "presura", que implicaba el reconocimiento de un derecho de posesión, muchas veces, supeditado al cultivo de la misma, otorgada por concesión del rey que podría llegar a transformarse en un derecho de propiedad como tal. Para mayor abundamiento sobre su naturaleza jurídica y su impacto como forma de adquisición de terrenos que habían quedado al abandono ante la desaparición de un gran número de propietarios, véase la obra del historiador Concha y Martínez, Ignacio de la, La "presura": la ocupación de tierras en los primeros siglos de la Reconquista, Madrid, Instituto Nacional de Estudios Jurídicos, 1946.

31 Ibidem, pp. 64 y 65.

32 Lomax, Derek W., The Reconquest of Spain, Londres-Nueva York, Longman, 1978, p. 232. Al-Andaluz es el nombre que le dan a la península ibérica los primeros musulmanes que entran en ella al mando de Tarik y Muza. El nombre procede, según la tradición, de los comentarios que los vándalos hicieron a los musulmanes a su paso por Túnez acerca de una tierra maravillosa refiriéndose a la península ibérica, por la que la llamaron "tierra de vandalus", García Gómez, María del Carmen y Ordaz Romay, Javier, Materiales para la historia de España, Madrid, Ediciones Akal, 2005, p. 8. 
Quizá sea, el otrora profesor de las universidades de Liverpool y Birmingham, uno de los autores que mayor plusvalía ha encontrado en la Reconquista española, pues otorga a dicho periodo de la historia de España un carácter conceptual profundo ${ }^{33}$ y una importancia tal, que lo lleva a aseverar su carácter imprescindible en el desarrollo del Viejo Mundo, porque a su decir, "es el primer ejemplo de reversión de una conquista islámica [que] aceleró el paso de la cultura griega y asiática a la Europa occidental", incluso refiere que "en la panorámica de la historia universal es un hecho vital porque preparó la rápida conquista y europeización de Iberoamérica y por lo tanto le evitó buena parte de las guerras imperialistas y de religión que a partir de entonces asolarían a casi todo el resto de la humanidad". ${ }^{34}$

La refutación o la confirmación de tales aseveraciones merecen muchas más líneas de las que son objeto del presente trabajo monográfico, por lo que será una asignatura pendiente que se habrá de retomar con posterioridad.

\section{NATURALEZA DEL DERECHO MEDIEVAL}

Parece existir una nota común cuando se habla de la sociedad medieval: el orden. La idea "de un orden subyacente de las cosas, donde la construcción jurídica se entiende como la construcción de ese orden". Un orden que precede a un derecho "caracterizado por un pluralismo de ordenamientos jurídicos, donde la presencia del Estado es casi nula y prácticamente indiferente ante la producción del derecho", que imbuye a un orden jurídico como "algo que brota de lo social y de la propia naturaleza de las cosas", algo así como el reflejo o "la interpretación de un orden natural y divino del mundo", en donde

33 Además de los significados que se han señalado al término Reconquista, el historiador mexicano Martín F. Ríos Saloma refiere que, tal y como lo señala Giorgio Perissinotto, el vocablo reconquista es un término polisémico, lo que le permite establecer cinco significados posibles: $a$ ) proceso histórico de naturaleza militar entre cristianos y musulmanes, $b$ ) periodo histórico en particular que se asimila a la Edad Media española comprendida de 718 a 1492, c) momento preciso en la historia medieval peninsular marcado por la conquista de una fortaleza, villa o ciudad por parte de los cristianos y su posterior reorganización política, administrativa y religiosa, $d$ ) referencia a una ideología creada por los distintos reinos hispanocristianos a lo largo de la Edad Media para restaurar el reino visigodo y e) referencia a una categoría de análisis historiográfico a partir de la cual se analizan las realidades medievales en la península ibérica. Ríos Saloma, F. Martín, La reconquista en la historiografía española contemporánea, México, UNAM, Instituto de Investigaciones Históricas, 2013, pp. 19 y 20.

34 Lomax, Derek W., The Reconquest..., cit., p. 232. 
sus creadores no hacen "más que revelar o descubrir ese orden". ${ }^{35}$ Un orden natural que según se entiende permitirá ir bordando junto a otros elementos adicionales, lo que a decir de Ferrajoli, será "toda la construcción teórica del Estado-persona que se desarrolla en la Edad Media", a partir de "la cultura jurídica iusnaturalista y racionalista" de dicha época donde se construye la figura de la "persona jurídica" como "artificio" o "ficción". ${ }^{36}$

De hecho, para algunos estudiosos de dicho periodo, como Rolando Tamayo y Salmorán, "los pensadores de la Edad Media comenzaron introduciéndose a las ideas políticas a través de la propia práctica gubernamental", misma que encuentra su más clara expresión "en la aplicación del derecho $y$, posteriormente, en su exposición académica que es la jurisprudencia", esto es, el derecho constituye la génesis de las ideas que permitirán resolver las grandes asignaturas políticas de la época. Una especie de "disciplina que se ocupa de la descripción de los actos de gobierno o de la conducción de la comunidad política, de los actos del poder público, a saber, la jurisprudencia". ${ }^{37}$

Es verdad que tales planteamientos no centran su estudio en el medievo español sino, en términos generales, en el europeo; no obstante esto, se estima que la esencia de su razonamiento guarda estrecha relación con el proceso medieval de los territorios españoles reconquistados bajo el auspicio normativo de los fueros, pues "las grandes cuestiones políticas como el imperio, la legitimación del monarca y la Iglesia, fueron abordadas por la jurisprudencia medieval", lo que según su perspectiva propició que "los argumentos del debate político de la Edad Media fueran forjados por las manos de los juristas". ${ }^{38}$ Es ahí, justamente, donde se piensa que se inscribe el derecho foral producido durante la Reconquista española.

35 Fuentes López, Carlos, El racionalismo jurídico, México, UNAM, Instituto de Investigaciones Jurídicas, 2013, pp. 41 y 42.

36 Ferrajoli, Luigi, Principia iuris. Teoría del derecho y de la democracia, trad. de Perfecto Andrés Ibáñez et al., Madrid, Trotta, 2011, p. 159.

37 Tamayo y Salmorán, Rolando, Los publicistas medievales y la formación de la tradición politica de Occidente. Estudio histórico sobre la recepción de la ciencia jurídica y su impacto en las ideas políticas, México, UNAM, Instituto de Investigaciones Jurídicas, 2016, pp. 6 y 7.

38 Ibidem, p. 17. Para el citado autor, el hecho de que el derecho romano y la jurisprudencia medieval "hayan ejercido enorme influencia en la estructuración política de Europa, en la formación de su ideología política, es un hecho indiscutible. Su impacto en las ideas y en la práctica gubernamental no tuvo paralelo. Su peso y su fuerza se debe, sin duda, a que el "derecho romano" era la madura expresión de las más ecuménica de todas las ideas 
Un derecho medieval "de formación jurisprudencial y doctrinal" que, si bien es cierto, no incluye aun dentro de sus preocupaciones conceptos como "poder constituyente", ni el concepto de soberanía como "un principio moderno que se afirma con la formación de los Estados nacionales, junto al principio de legalidad y del monopolio estatal de la producción jurídica", en el momento en que se "afirma como positivo y artificial" debe admitir "la existencia de una subjetividad, de una potestad y de una actividad constituyente", ${ }^{39}$ ampliamente estudiada y desarrollada a partir de esas primeras manifestaciones por los grandes pensadores clásicos del constitucionalismo moderno.

En ese sentido, el universo medieval tiene como rango distintivo la expresión de "un poder político incompleto", no por una falta de efectividad, sino por la "ausencia de un proyecto totalizador", con una consecuencia relevante que es la existencia de sociedades "fundamentalmente autónomas, sin constricciones vinculantes, dejadas libres", que es justamente donde "brota y se sitúa el derecho", que no es fruto de un sujeto determinado, sino una realidad histórica que "nace de las vastas espiras de la sociedad con la que se mezcla, a la que se incorpora", fundada "sobre el credo religioso, el oficio, la solidaridad cooperativa, sobre la colaboración económica"; en suma: "primero existe el derecho; el poder político viene después". ${ }^{40}$

Contra esa percepción - que en buena medida sugiere la falta de un Estado como tal, como "sujeto político fuerte, encarnación de un poder político perfectamente completo"-, ${ }^{41}$ se pronuncia Raúl Pérez Johnston quién asevera que "la Edad Media no sólo tiene Estado como lo entendemos actualmente, sino que además es uno de los periodos más fecundos en ideas políticas de la historia", ${ }^{42}$ lo que resulta coincidente con la tesis ya antes

occidentales; simbiosis bizantina de jurisprudencia y tradición romanas, cultura griega y doctrina cristiana".

39 Ferrajoli, Luigi, op. cit., p. 158.

40 Grossi, Paolo, Mitología jurídica de la modernidad, trad. de Manuel Martínez Neira, Madrid, Trotta, 2003, pp. 24 y 25.

41 Grossi, Paolo, El orden jurídico medieval, trad. de Francisco Tomás y Valiente y Clara Álvarez, Madrid, Marcial Pons, 1996, p. 62. En dicha obra, el autor abunda respecto de su concepción del Estado o de "la levedad del poder político". Señala que la idea de que el Estado sea una presencia irrenunciable no tanto del escenario histórico como de nuestra conciencia de modernos, es porque "somos hijos de una Edad Moderna, que mediante un lento proceso desde el siglo XIV en adelante, vive de la presencia cada vez más obstaculizante de este sujeto político, que lo hace protagonista ayer y hoy de su vida en asociación".

42 Pérez Johnston, Raúl, "Los aportes del derecho público medieval a la teoría del Estado y de la Constitución. Diálogo con Paolo Grossi”, Historia Constitucional, núm. 5, 2004, 
descrita de Tamayo y Salmorán en cuanto a la consideración del medievo como una tierra fértil para las teorías políticas modernas. Ello se refuerza cuando Johnston afirma que la caída del imperio romano produjo un gran vacío político, el cual sería llenado por el derecho, por lo que comparte la idea de que la Edad Media debe ser vista como un "anagrama de la civilización jurídica". ${ }^{43}$

Así, se tiene que la naturaleza y la función del derecho medieval, incluido desde luego, el elaborado en los reinos españoles, obedece más a una producción social que a una actividad vinculada a los órganos del Estado tal y como se conciben hoy en día ${ }^{44}$ Asimismo, se tiende a otorgársele una función "radical y fundante de la sociedad, un cimiento estable que destaca respecto al desorden y la mutabilidad de lo cotidiano", por lo que la sociedad medieval "es jurídica porque se cumple y se salva en el derecho, porque jurídica es su más profunda constitución y allí está su rostro esencial, su clave última". ${ }^{45}$

Fenómenos que no son menores y que resultan necesarios para entender una época tildada de oscurantista, pero que en los primeros atisbos que se le realizan ofrece grandes campos de estudio y enseñanza para entender la evolución del derecho hasta nuestros días, tarea esencial de la historia del derecho cuya "función formativa" para el estudiante del derecho es "conocer el origen y sentido del derecho vigente y de las instituciones jurídicas, para así no errar en la interpretación de las normas jurídicas, ni adoptar modelos extraños sin el juicio crítico adecuado", ${ }^{46}$ amén de ser el punto de partida en la conformación del Estado moderno y de las ideas políticas que lo justifican y que lo imbuyen.

\section{EL DERECHO FORAL EN LA ESPAÑA MEDIEVAL}

Así como existen autores que etiquetan el proceso de la Reconquista bajo el concepto tradicional histórico de haber sido un cometido nacional para la re-

p. 278, disponible en http://www.historiaconstitucional.com/index.php/historiaconstitucio nal/article/view/104/89.

43 Idem.

44 El derecho en el mundo medieval, afirma Grossi, "pertenece a las entrañas de la sociedad". Grossi, Paolo, Un estado sin derecho. La noción de autonomía como fundamento de la constitución jurídica medieval, p. 173, disponible en http://www.juridicas.unam.mx/publica/ librev/rev/hisder/cont/9/cnt/cnt5.pdf.

45 Grossi, Paolo, El orden jurídico..., cit., p. 35.

46 Cruz Barney, Oscar, Historia del derecho indiano, Valencia, Tirant lo Blanch, 2012, p. 13. 
cuperación de los territorios perdidos frente a los musulmanes, hay también quienes lo ven como la "forma de organización de la sociedad en las distintas regiones de la Península Ibérica", ${ }^{47}$ puntualizando los orígenes sociales de la Reconquista.

Es esa percepción social y consuetudinaria ${ }^{48}$ la que se manifiesta de manera preponderante en la forja y expedición de cada uno de los fueros y cartas pueblas emitidas en dicho periodo como instrumentos indispensables para la fundación y subsistencia de las nuevas poblaciones reconquistadas, ${ }^{49}$ lo que propicio "un derecho de vigencia territorial limitada a ámbitos restringidos", ${ }^{50}$ siendo esa la capacidad creadora desarrollada por el derecho altomedieval español, que recibió ciertas "influencias del derecho musulmán y del judío en materias fiscal y agrícola", ${ }^{51}$ entre otras materias.

En ese orden de ideas, es preciso destacar que existieron diversos tipos de fueros, concebidas como "las cartas expedidas por los reyes, y, en su caso, por algunos señores, en virtud del privilegio dimanado de la soberanía en la que se contienen un conjunto de normas destinadas al buen gobierno de las villas y ciudades", ${ }^{52}$ que eran — según refiere Cruz Barney - una creación esencialmente popular y consuetudinaria. ${ }^{53}$ Así, existieron las cartas pueblas de índole agraria y unilateral, cuya finalidad era eminentemente

47 Barbero, Abilio y Vigil, Marcelo, Sobre los orígenes sociales de la Reconquista, Barcelona, Ariel, 1974, pp. 5 y 6 . Incluso para dichos autores los problemas que implican esa visión tradicional "son ficticios".

48 "Derecho y tradición se identifican; el derecho antiguo, permanente, estable, de hecho, cuanto más viejo mejor, pues tiene mayor autoridad [...] un derecho popular y sencillo [...] el derecho como privilegio: las normas jurídicas legitiman las diferencias sociales porque las plasma. El derecho diferencia, no unifica. No existe el principio de igualdad de los hombres ante la ley”. Cruz Barney, Oscar, Historia del..., cit., pp. 73-75.

49 El español Tomás Muñoz y Romero, quién en 1847 publicara una importante colección de fueros municipales y cartas pueblas subsistentes a esa fecha, en su advertencia a dicha obra señala que España debe al régimen foral haber destacado en la Edad Media respecto de las demás naciones de Europa "en la perfección de su estado social y político", pues agrega "en los fueros municipales y en las cartas de población está consignada la historia de su cultura, desde la época de la Reconquista hasta fines del siglo XIV". Muñoz y Romero, Tomás, Colección de fueros municipales y cartas pueblas de los reinos de Castilla, León, Corona de Aragón y Navarra, Madrid, edición facsimilar, 1972, p. 3.

50 Ibidem, p. 81.

51 Cruz Barney, Oscar, Historia del..., cit., p. 73.

52 López Villalba, José Miguel, "Los fueros y ordenanzas medievales: embrión del gobierno de los cabildos coloniales hispanoamericanos", Historia. Instituciones. Documentos, Universidad de Sevilla, núm. 33, 2006, p. 340.

53 Para Cruz Barney, el fuero fue el instrumento jurídico más importante de la Reconquista entendido en tres sentidos: "i) Como norma jurídica singular, ii) como conjunto de 
apuntalar la repoblación de las ciudades o villas que se iban conformando. Cruz Barney cita como las más representativas las de Freixá del 954, la de Horta de 1192 y la de El Espinar de 1297.

Los fueros breves o de franquicias, propios de los siglos XI y XII, "se concedían a una ciudad o villa con la finalidad de fijar o ampliar su régimen jurídico", lo que implicaba el ejercicio de ciertos derechos, sin que llegaran a "otorgar plena autonomía a la comunidad". Dadas sus particularidades, en torno a los mismos llegaron a producirse "de manera constante luchas entre los burgueses y los señores, en donde los primeros defendían sus privilegios frente a los segundos". ${ }^{54}$

Asimismo, el nombre de fuero breve obedece a que "normalmente no contenían más de cincuenta o sesenta disposiciones, en las que se explican las obligaciones de los colonizadores hacia su señor", fue así, un tipo de derecho local sustraído de casos o conflictos concretos de la cotidianidad, por lo que constituyeron la base de "muchas de las normas recogidas en los fueros extensos". 55

Por su parte, los fueros municipales extensos de los siglos XII y XIII "contenían privilegios importantes, exenciones y normas de la ley consuetudinaria sobre asuntos penales y procesales", ${ }^{56}$ además de que muchas veces contenían cerca de mil disposiciones. Entre ellos, destaca el llamado Fuero Real de 1256 expedido por Alfonso X, importante recopilación de distintas normas (cartas pueblas, decretos reales, normas judiciales y leyes locales) que poco a poco fue supliendo determinados fueros locales, coadyuvando a la posterior conformación de un régimen municipal, dado que "contenían un derecho vivo, positivo y era defendido a capa y espada por los burgueses". ${ }^{57}$

normas vigentes en un lugar determinado, y iii) como conjunto de normas vigentes en un lugar determinado y recogidas en un texto". Cruz Barney, Historia del..., cit., p. 76.

54 Francisco Tomás y Valiente, cit. en ibidem, p. 78.

55 Dillard, Heath, La mujer en la Reconquista, trad. de Concepción Fernández, Madrid, Nerea, 1993, p. 16.

56 Ibidem, p. 17. Para dicho investigador, el número considerable de fueros municipales se debió "principalmente a las condiciones especiales de la Reconquista, a la incorporación gradual de los territorios que previamente habían sido de los musulmanes y a las necesidades cambiantes de las comunidades que se estaban desarrollando, las circunstancias exigían métodos nuevos para la organización de los municipios", p. 18.

57 Cruz Barney, Oscar, Historia del..., cit., p. 81. Dicho autor cita la definición de fueros extensos elaborada por José Manuel Pérez-Prendes Muñoz-Arraco en los siguientes términos: "conjunto de normas jurídicas que regulan la vida local y las cargas y derechos de los 
Además, Heath Dillard destaca que en esa misma época (siglos XII y XIII) surgieron ciertas concesiones o mandatos dictados por el rey y normas derivadas de decisiones judiciales ejemplares, también conocidas como fazañas. Una suerte de precedentes judiciales que se obtenían "gracias a sentencias de casos problemáticos locales o regionales" 58 que se traían a colación con posterioridad para la resolución de asuntos.

Los fueros extensos más representativos del medievo español fueron dos, ${ }^{59}$ surgidos a raíz de "una política real tendiente a unificar los derechos [o fueros] locales": ${ }^{60}$ el Fuero Juzgo o Liber Iudiciorum (promovido por Fernando III) y el ya citado Fuero Real, siendo este último posteriormente retirado por su autor, dado el rechazo de las cortes, al haber incorporado instituciones inspiradas en el derecho romano que conllevó "diversas dificultades derivadas de su aplicación", ${ }^{61}$ mientras que el primero fue ampliamente adoptado por varias ciudades, entre ellas, Toledo, Sevilla, Córdoba, Alicante, Murcia y Jerez, lo que según refiere Cruz Barney preparó la recepción del derecho común en Castilla.

Mención aparte merece el ya referido trabajo de Heath Dillard, en torno al papel de la mujer o de las villanas durante el proceso de Reconquista, pues parece ser uno de los pocos trabajos que abordan dicha temática, que resulta de las más relevantes para el éxito de dicha encomienda. Dillard reconoce que es "cierto que los fueros carecen de una voz auténticamente femenina, pero ello no es obstáculo insuperable cuando se trata de obtener de ellos informes razonablemente precisos sobre las villanas", ${ }^{62}$ quienes eran tan importantes como los hombres para el éxito a largo plazo de la empresa de expansión y repoblación en la Reconquista; por ello, asevera, las mujeres desempeñaron un rol relevante "como colonizadoras, esposas de coloniza-

vecinos y moradores, recogido en una redacción o texto único que es dada o recibe la confirmación del rey o del señor", p. 80.

58 Dillard, Heath, op. cit., p. 16.

59 En la ya citada obra de Tomás Muñoz, se da cuenta de alrededor de 162 fueros, cartas pueblas, donaciones, privilegios y confirmaciones de fueros que datan de los años 780 a 1144. Tomás y Valiente, Francisco, Manual de historia del derecho español, Madrid, Tecnos, 2001, pp. 551-558. Asimismo, puede verse la obra del hispanista sueco Gunnar Tilander relativa a los fueros aragoneses promulgados a consecuencia de la gran peste negra o peste bubónica de 1348, una de las más devastadoras de la historia de la humanidad. Tilander, Gunnar, Fueros aragoneses desconocidos promulgados a consecuencia de la gran peste de 1348, Suecia, Offset Lito Stockholm, 1959.

60 Cruz Barney, Oscar, Historia del..., cit., p. 82.

61 Ibidem, p. 84.

62 Dillard, Heath, op. cit., p. 22. 
dores, madres de generaciones sucesivas de defensores y miembros vitales de las nuevas comunidades hispánicas", ${ }^{63}$ mujeres a las que al otorgárseles ciertos derechos en las nuevas comunidades, tomaban la decisión de permanecer en ellas, consolidando dichos asentamientos.

En suma, como se observa, existía un sistema jurídico de carácter local plural y fragmentado "como orden escrito en las raíces más profundas de la naturaleza y de la sociedad, [como] una dimensión óntica que debía únicamente constatarse, leerse", ya que provenía de un origen consuetudinario y no de una hechura legislativa propiamente dicha, carente de un principio de legalidad como tal, lo que "constituye el signo de mayor evidencia del profundo foso de discontinuidad que separa la experiencia jurídica moderna de aquella medieval". ${ }^{64}$ No obstante lo anterior, existen autores que ven en la evolución legislativa de los fueros hacia las ordenanzas entendidas "como toda norma general, cualquiera que fuera su autor, cuyo ámbito territorial se circunscriba al municipio", el embrión de la normativa municipal que vendrá a regular las relaciones sociales de los municipios, "esquema que se reproducirá al otro lado del Atlántico", donde el principio normativo "fue la guía de la vida urbana de los territorios americanos", ${ }^{65}$ destacándose así una herencia particular del derecho foral medieval español.

Tendrían que pasar cientos de años más para que la idea de un Estado de derecho (que después evolucionaría a la de un Estado constitucional y posteriormente a la de un Estado neoconstitucional) comience a acaparar los reflectores del pensamiento jurídico. Según Zagrebelsky, el siglo XIX es el siglo del Estado de derecho: una de las expresiones "más afortunadas de la ciencia jurídica contemporánea", en donde el citado principio de legalidad:

expresa la idea de la ley como acto normativo supremo e irresistible, al que en principio no es oponible ningún derecho más fuerte, cualquiera que sea su forma y fundamento; ni el poder de excepción del rey, ni la inaplicación por parte de jueces o la resistencia de particulares, en nombre de un derecho más alto (el derecho natural o el derecho tradicional) o de derechos especiales (los privilegios locales o sociales). ${ }^{66}$

Es así que se afirma la derrota de las tradiciones jurídicas del absolutismo y del Ancien régime por el imperio de la ley, lo cual implicó en la práctica

63 Ibidem, p. 28.

64 Grossi, Paolo, De la codificación a la globalización del derecho, trad. de Rafael D. García Pérez, Madrid, Thomson Reuters, 2010, p. 364.

65 López Villalba, José Miguel, op. cit., pp. 350-355.

66 Zagrebelsky, Gustavo, El derecho dúctil. Ley, derechos, justicia, trad. de Marina Gascón, Madrid, Trotta, 2011, pp. 21-25. 
un nuevo paradigma en la confección del derecho, la monopolización en su manufactura y el abandono de la costumbre medieval como una de las principales fuentes normativas. ${ }^{67}$

\section{EL DERECHO FORAL CONTEMPORÁNEO}

Para el jurista e historiador español Bartolomé Clavero, la incompatibilidad surgida entre el constitucionalismo y el derecho foral obedece, entre varias razones, a un principio jurídicamente constituyente, así como a la predominancia de la institución legislativa del Parlamento. Para él, en los orígenes de la España constitucional, la cuestión llega a plantearse "en los términos de una confrontación radical entre Constitución y fuero, entre sistema constitucional y derechos históricos". Empero, señala que en algunas regiones españolas, durante la época contemporánea, "el motivo histórico de los fueros ha resistido notoriamente a las condiciones más desfavorables, entre las que se puede contarse el mismo desconocimiento o aun el desprecio", lo que indica tuvo mayor fuerza en el siglo XIX, en el que estuvo en juego la lucha "entre un derecho castellano expansivo y unos derechos regionales resistentes". ${ }^{68}$

No obstante esa aparente discordancia, el derecho foral ${ }^{69}$ circunscrito al derecho civil adquirió cierta autonomía y presencia en la normativa españo-

67 Costumbre que en sus orígenes constituyó una especie de lex non scripta "que se había sedimentado en la vida de los conjuntos humanos porque respondía a las posibilidades que éstos demandaban de ella, así la praxis diaria se convirtió en una especie de repositorio non scripto donde se buscaban soluciones para redactar por escrito las nuevas leyes, todo ello sucedió en cada punto de población por pequeño que fuera", lo que evolucionó con el tiempo y con la consolidación de nuevas poblaciones, por lo que "el resultado fue una tendencia generalizada hacia la consolidación de la lege scripta como consecuencia del intervencionismo de entidades superiores que otorgaban leyes pretendiendo extender y uniformar, lo que en principio se presentaba como un conjunto de disposiciones particularizadas". López Villalba, José Miguel, op. cit., p. 339.

68 Clavero, Bartolomé, El código y el fuero. De la cuestión regional en la España contemporánea, Madrid, Siglo XXI Editores, 1982, pp. 1-6.

69 Para Castán Tobeñas, la denominación derecho foral no es perfectamente adecuada para significar los particularismos legislativos que en el orden civil existen en España. Especialmente es impropia con relación a la legislación catalana, en la cual, las palabras fuero y foral son exóticas. No obstante señala que no hay inconveniente en mantener la expresión de derecho foral o derechos forales, que tiene su apoyo en razones históricas y "está incorporada con tanto arraigo a nuestro actual tecnicismo jurídico, siempre que no se dé a la misma el sentido que algún importante sector de la doctrina científica pretende atribuirle hoy de legislación excepcional y particularista, hija del privilegio y la gracia de reyes y señores". Castán Tobeñas, José, op. cit., t. I, p. 284. 
la reciente, aun cuando "las constituciones no pudieran concebir que en los ámbitos más decisivos del sistema jurídico, se definiese un derecho sin la verdadera mediación del poder legislativo por ellas establecido". ${ }^{70}$ Resultado de ello, son las recopilaciones realizadas en el siglo pasado en distintas regiones de España, entre ellas, Aragón, Navarra y Cataluña, tomando en cuenta su vigencia y su aplicabilidad acorde a las necesidades presentes, lo que permite hablar de un derecho civil común y un derecho civil foral, entendido este último, según Castán Tobeñas, como "un conjunto de privilegios locales heterogéneos que, como derecho excepcional no derogado, se conserva en ciertos territorios que tuvieron fueros o costumbres especiales", ${ }^{71}$ un derecho eminentemente excepcional que sobrevivió de alguna manera con cierta autonomía a los esfuerzos codificadores iniciados a principios del siglo XIX y a los intentos de consolidar una legislación unificadora. ${ }^{72}$

De esa manera, los derechos forales ${ }^{73}$ forman en sus respectivos territorios "un sistema jurídico análogo al del Código, aunque éste sea más amplio y más concreto", principalmente en temas como el derecho familiar y sucesorio, lo que ya supone un importante problema de coexistencia y coordinación entre derecho común y derechos forales, que "constituyen todavía un sistema de principios y reglas que rigen la vida de los naturales de cada región en todos los aspectos a que son aplicables, que los tribunales tienen obligación de conocer y cuyas normas ocupan en la jerarquía de las fuentes del respectivo territorio igual lugar que las del Código Civil en los de derecho común". ${ }^{74}$

Esa persistencia o convivencia no es casual; ha influido sustancialmente la multiculturalidad y la existencia de zonas autonómicas en el actual territorio español. Es fruto de una tradición jurídica arraigada en varias regiones

70 Clavero, Bartolomé, op. cit., p. 27.

71 Castán Tobeñas, José, op. cit., p. 284.

72 El proceso unificador implicó "dos ámbitos diferenciados entre sí”, por un lado, la legislación civil, y por el otro, "las instituciones político-administrativas, militares y tributarias". La publicación de un Código civil implicó para algunos juristas la desaparición de los derechos forales, sin embargo, en la "promulgación del Código civil de 1889 no hubo una unificación total en materia civil". Tomás y Valiente, Francisco, op. cit., pp. 564-565.

73 En ese sentido, "el derecho foral no debe confundirse con los fueros y privilegios concedidos a los municipios durante la Edad Media, porque no se trata de la legislación privilegiada de los habitantes de una ciudad, sino de normas que afectan la generalidad de los naturales del territorio en que están vigentes". Lacruz Berdejo, José Luis, Estudios de derecho privado común y foral, Madrid, José María Bosch editor, t. I, 1992, p. 30.

74 Idem. 
como Aragón, Mallorca, Valencia, Navarra o Cataluña, en donde perviven ciertos derechos forales ${ }^{75}$ sustentados "en la bondad intrínseca de su contenido, debida en buena parte al profundo respeto a la voluntad del individuo que en ellos impera, y al vivo sentido de la equidad patente a través de sus preceptos", los que sin embargo, "viven precariamente, a causa de que no coinciden con la legislación de la mayor parte del territorio español". ${ }^{76}$

Pero, además, ese valor ha originado que el derecho foral encuentre asidero en el mismo texto constitucional ${ }^{77}$ y en el código civil español vigente. ${ }^{78}$ Esto es, el influjo del derecho foral ha permeado de forma tal que se le reconoce vigencia y aplicabilidad, lo que implica la coexistencia de un derecho general y uno particular foral de cada región española, "ahí donde el mismo exista", sin que tal circunstancia sea considerada una cuestión de vida o muerte, ya que "unida España en lo político, el que el derecho civil de unos territorios sea distinto del de otros es un hecho que, entre los apremiantes problemas de la vida de una nación moderna, apenas atrae la atención pública", ${ }^{79}$ máxime que el practicante del derecho suele ser uniformista en la aplicación del derecho.

Es claro, entonces, que hoy existe la obligación constitucional de reconocer el derecho foral existente, de manera particular en cuanto hace al derecho civil, y con mayor énfasis respecto de determinadas figuras e instituciones (relaciones familiares y sucesiones), bajo determinadas reglas de

75 En el siglo XIX solían denominarse territorios forales o territorios del derecho foral a todos los que tenían un régimen jurídico propio y distinto al común vigente en el resto de la nación. Tomás y Valiente, Francisco, op. cit., p. 565.

76 Ibidem, pp. 31-35.

77 "Artículo 149. El Estado tiene competencia exclusiva sobre las siguientes materias [...] 8a. Legislación civil, sin perjuicio de la conservación, modificación y desarrollo por las Comunidades Autónomas de los derechos civiles, forales o especiales, allí donde existan. En todo caso, las reglas relativas a la aplicación y eficacia de las normas jurídicas, relaciones jurídico-civiles relativas a las formas de matrimonio, ordenación de los registros e instrumentos públicos, bases de las obligaciones contractuales, normas para resolver los conflictos de leyes y determinación de las fuentes del derecho, con respeto, en este último caso, a las normas de derecho foral o especial".

78 El Código Civil en el capítulo V denominado "Ámbito de aplicación de los regímenes civiles coexistentes en el territorio nacional”, prescribe lo siguiente en su artículo 13.2: "En lo demás, y con pleno respeto a los derechos especiales o forales de las provincias o territorios en que están vigentes, regirá el Código Civil como derecho supletorio, en defecto del que lo sea en cada una de aquéllas, según sus normas especiales". Asimismo, el artículo 14.1 dispone: "La sujeción al derecho civil común o al especial o foral se determina por la vecindad civil".

79 Lacruz Berdejo, José Luis, op. cit., p. 36. 
prelación ${ }^{80}$ en cuanto a su aplicación en cada uno de los territorios donde se hace presente.

Un ejemplo palpable y reciente de lucha por la recuperación y vigencia del derecho foral, es el que ha protagonizado La Generalitat (conjunto de instituciones de autogobierno) del reino de Valencia, constituido en comunidad autónoma a raíz de la promulgación de su Estatuto de Autonomía en $2006,{ }^{81}$ con la expedición, por parte de las Cortes, de tres leyes destinadas a recuperar el derecho civil valenciano de carácter foral, "siendo ésa una de las piezas más singulares de la arquitectura del autogobierno valenciano". ${ }^{82}$

Sin embargo, cabe precisar que el pasado 6 de mayo de 2016, el Tribunal Constitucional español determinó la inconstitucionalidad y nulidad de la Ley de la Comunidad Valenciana 10/2007, relativa al Régimen Económico Matrimonial Valenciano, al señalar que aun cuando la Constitución Española prevé en su artículo 149.1.8 la posibilidad de que las comunidades autónomas conserven, modifiquen y desarrollen los derechos civiles forales o especiales, "allí donde existan", lo cierto es que no se acreditó la pervivencia de las costumbres recogidas en dicha Ley, es decir, que la norma fundamental para el reconocimiento de dicha competencia exige la prueba de la existencia de esas disposiciones consuetudinarias, lo que no sucedió en la especie. ${ }^{83}$

Como puede apreciarse, aquí se trata de un caso práctico en el que se observa la importancia que el derecho foral, como normativa consuetudinaria susceptible de ser legislado por las comunidades autónomas según el propio

80 Al respecto, puede consultarse la obra de Albaladejo, Manuel, Curso de derecho civil español común y foral. Introducción y parte general, Barcelona, Librería Bosch, 1977, pp. 60-66. También la obra citada de Castán Tobeñas ofrece información precisa de la supletoriedad del derecho foral conforme a las diversas regiones que lo comprenden.

81 En el artículo 3.4 de dicho Estatuto se prevé de manera expresa la aplicación del derecho civil foral valenciano. De igual forma, el artículo 7.1 señala: el desarrollo legislativo de las competencias de La Generalitat procurará la recuperación de los contenidos correspondientes de los fueros del histórico Reino de Valencia en plena armonía con la Constitución y con las exigencias de la realidad social y económica valenciana. Esta reintegración se aplicará, en especial, al entramado institucional del histórico Reino de Valencia y su propia onomástica en el marco de la Constitución Española y de este Estatuto de Autonomía.

82 Véase la nota publicada al respecto en la edición electrónica de El País, intitulada "El complicado derecho foral valenciano. Las Cortes han aprobado tres leyes destinadas a recuperar el derecho civil valenciano", el 15 de mayo de 2016, disponible en http://ccaa.elpais. com/ccaa/2014/01/01/valencia/1388602977_861718.html.

83 Puede consultarse el boletín emitido por dicho Tribunal Constitucional, disponible en http://www.tribunalconstitucional.es/es/salaPrensa/Documents/NP_2016_046/Nota\%20 Informativa\%20n\%C2\%BA\%2046-2016.pdf. 
texto constitucional, tiene en ciertas regiones de España donde convive con el derecho civil general codificado, así como el criterio o la postura que el Tribunal Constitucional tiene respecto a la vigencia y aplicabilidad de determinados preceptos forales.

\section{CONCLUSIONES}

Pocas veces el estudiante y el profesional del derecho se detienen a observar con detenimiento las expresiones y producciones jurídicas desarrolladas durante la Edad Media. Con frecuencia se cree que el derecho medieval no es otra cosa que la prolongación de un derecho romano divulgado y en ocasiones ampliamente arraigado en algunas zonas de Europa.

Al respecto, sin embargo, la historiografía ofrece distintas interpretaciones de las circunstancias que rodearon el devenir histórico del derecho en el alto y bajo medievo español. Muchos de ellos son puntos de vista de historiadores que con excelente oficio reconstruyen a detalle dichos acontecimientos, y otros tantos son de juristas avezados que proporcionan su interpretación particular acerca de los hechos históricos que han sido mencionados. De este maremágnum de datos e información se pueden extraer las siguientes conclusiones acerca de lo que significó el proceso de Reconquista español, y el derecho específico, producido a la vez, conocido en términos generales como disposiciones forales.

1) El proceso de Reconquista no es un término, historiográficamente hablando, unívoco. Sin embargo, puede decirse que, en términos generales, refiere a la recuperación, por parte de los españoles, de los territorios ocupados por los musulmanes, lo que tuvo lugar entre 711 y 1492, fecha última en que se realizó la unificación de los reinos hispanos.

2) Existe cierto consenso para aseverar que el proceso de Reconquista fue permanente y continuado durante los más de siete siglos que implicó la ocupación árabe. Fue una especie de misión perenne enquistada en el espíritu de los conquistados, en el que la mujer desempeñó un rol determinante para la consolidación de los nuevos asentamientos implantados en los territorios reconquistados.

3) La inercia reconquistadora facilitó el proceso de conquista de América, por parte de unos españoles sabedores de lo intrincado que podría haber resultado el establecimiento de nuevas comunidades y las 
exigencias de toda índole que las mismas suponen, entre ellas, un marco normativo mínimo para su desarrollo.

4) España es un territorio marcado por la multiculturalidad desde sus orígenes. Una pluralidad que evidentemente se manifiesta en los distintos sectores de una sociedad, entre ellos, desde luego en la variada normativa que se gestó y que imperó en las diversas regiones españolas que la conformaron después. Pluralismo que se refleja hoy en día con la existencia de comunidades autónomas que demandan la vigencia de ciertas costumbres normativas forales de carácter local.

5) Según los estudiosos del derecho medieval español, éste nace como un producto netamente consuetudinario y popular, obviamente bajo cierto influjo del derecho romano, pero podría decirse netamente artesanal y casuístico. Un derecho del día a día, jurisprudencial, que surge en un entorno en el que la idea y la acción del Estado no habían sido aún articuladas.

6) De ahí que el papel de los fueros fue precisamente acompañar el proceso de Reconquista español. Fueron un arma que permitió incentivar y consolidar el gradual avance de dicho proceso repoblacional. Es más, se estima que la Reconquista está indisolublemente ligada a la aparición de ese derecho jurisprudencial foral al que incluso le es atribuido ser el germen de las ideas políticas acerca del gobierno y del Estado que se desarrollarán con posterioridad. Existe pues, una especie de simbiosis o dependencia entre los fueros expedidos y la Reconquista española.

7) Es un hecho que al ser las normas forales una creación consuetudinaria, ajena a una acción legislativa estatal como tal, hayan tenido que sortear determinados prejuicios y vicisitudes a raíz de la aparición del constitucionalismo moderno. Se produjo una colisión que derivó en la prevalencia del derecho del Estado y del principio de legalidad, debido a una explicación que se antoja sencilla: uno es el derecho de la gente, el otro es un derecho impuesto por el Estado.

8) Quizá sea esto último, lo que explique la coexistencia de un derecho foral de corte esencialmente civil y un derecho civil general en la España de nuestros días. Un derecho foral que no ha podido ser soslayado ni por la Constitución, ni por el Código Civil español que lo reconocen, e incluso, lo promueven. Tal normativa constitucional y legal no ha tenido otro remedio. El derecho foral está ahí como un derecho especializado, como un derecho de la gente, como un derecho de todos los días, que al parecer sigue desempeñando su 
mismo papel ancestral que en la Reconquista: acompañar y regir a la pluralidad española. Una multiculturalidad milenaria que supone ser su más grande virtud, pero también, parte de una cierta debilidad institucional.

\section{BIBLIOGRAFÍA Y HEMEROGRAFÍA}

Albaladejo, Manuel, Curso de derecho civil español común y foral. Introducción y parte general, Barcelona, Librería Bosch, 1977.

BARbero, Abilio y VigiL, Marcelo, Sobre los orígenes sociales de la Reconquista, Barcelona, Ariel, 1974.

CASTÁn ToBeñas, José, Derecho civil español, común y foral, Madrid, Reus, 1975 , t. I.

Clavero, Bartolomé, El código y el fuero. De la cuestión regional en la España contemporánea, Madrid, Siglo XXI Editores, 1982.

Cruz Barney, Oscar, Historia del derecho en México, México, Oxford University Press, 2004.

Cruz Barney, Oscar, Historia del derecho indiano, Valencia, Tirant lo Blanch, 2012.

CONCHA Y MARTínez, Ignacio de la, La "presura": la ocupación de tierras en los primeros siglos de la Reconquista, Madrid, Instituto Nacional de Estudios Jurídicos, 1946.

DillaRD, Heath, La mujer en la Reconquista, trad. de Concepción Fernández, Madrid, Nerea, 1993.

Ferrajoli, Luigi, Principia iuris. Teoría del derecho y de la democracia, trad. de Perfecto Andrés Ibánez et al., Madrid, Trotta, 2011.

Fuentes LóPEz, Carlos, El racionalismo jurídico, México, UNAM, Instituto de Investigaciones Jurídicas, 2003.

García Gómez, María del Carmen y Ordaz Romay, Javier, Materiales para la historia de España, Madrid, Ediciones Akal, 2005.

Grossi, Paolo, De la codificación a la globalización del derecho, trad. de Rafael D. García Pérez, Madrid, Thomson Reuters, 2010.

Grossi, Paolo, El orden jurídico medieval, trad. de Francisco Tomás y Valiente y Clara Álvarez, Madrid, Marcial Pons, 1996.

Grossi, Paolo, Europa y el derecho, trad. de Luigi Giuliani, Barcelona, Crítica, 2008.

Grossi, Paolo, Mitología jurídica de la modernidad, trad. de Manuel Martínez Neira, Madrid, Trotta, 2003. 
Grossi, Paolo, "Un derecho sin estado. La noción de autonomía como fundamento de la constitución jurídica medieval", Anuario Mexicano de Historia del Derecho, México, vol. IX, 1997.

HäBERLe, Peter, El Estado constitucional, trad. de Héctor Fix-Fierro, Buenos Aires, Astrea, 2007.

LaCruz Berdejo, José Luis, Estudios de derecho privado común y foral, Madrid, José María Bosch Editor, 1992, t. I.

Lomax, Derek W., La Reconquista, trad. de Antonio Prometeo Moya, Barcelona, Crítica, 1984.

Lomax, Derek W., The Reconquest of Spain, Londres-Nueva York, Longman, 1978.

López VillaLba, José Miguel, "Los fueros y ordenanzas medievales: embrión del gobierno de los cabildos coloniales hispanoamericanos", Historia. Instituciones. Documentos, Universidad de Sevilla, núm. 33, 2006.

Maine, Henry, El derecho antiguo, trad. de Ramón Cotarelo, Valencia, Tirant lo Blanch, 2014.

MARGADANT S., Guillermo F., Introducción a la historia del derecho mexicano, México, Esfinge, 1986.

Margadant S., Guillermo F., Panorama de la historia universal del derecho, México, Miguel Ángel Porrúa, 1998.

Mina APAT, María Cruz, Fueros y revolución liberal en Navarra, Madrid, Alianza Editorial, 1981.

MuÑoz y Romero, Tomás, Colección de fueros municipales y cartas pueblas de los reinos de Castilla, León, Corona de Aragón y Navarra, Madrid, 1972, facsímil.

PÉREZ, Joseph, La historia de España, trad. de Juan Vivanco, Magda Mirabet y M. Carmen Doñate, Barcelona, Crítica, 2006.

Pérez Johnston, Raúl, "Los aportes del derecho público medieval a la teoría del Estado y de la constitución. Diálogo con Paolo Grossi", Historia Constitucional. Revista Electrónica de Historia Constitucional, núm. 5, 2004.

Ríos Saloma, F. Martín, La Reconquista en la historiografía española contemporánea, México, UNAM, Instituto de Investigaciones Históricas, 2013.

SuÁrez BilbaO, Fernando, "El modelo de organización política de la monarquía universal: la corona de Aragón y su proyección en las Indias", Revista Mexicana de Historia del Derecho, México, vol. XXX, julio-diciembre de 2014. 
TAMAYO Y SALMORÁn, Rolando, Los publicistas medievales y la formación de la tradición política de Occidente. Estudio histórico sobre la recepción de la ciencia jurídica y su impacto en las ideas políticas, México, UNAM, Instituto de Investigaciones Jurídicas, 2016.

Tilander, Gunnar, Fueros aragoneses desconocidos promulgados a consecuencia de la gran peste de 1348, Suecia, Offset Lito Stockholm, 1959.

Tomás y Valiente, Francisco, Manual de historia del derecho español, Madrid, Tecnos, 2001.

Zagrebelsky, Gustavo, El derecho dúctil. Ley, derechos, justicia, trad. de Marina Gascón, Madrid, Trotta, 2011. 